Sumiyati

\title{
UPAYA MENINGKATKAN MOTIVASI BELAJAR IPS SISWA SMP MELALUI PEMBELAJARAN CONTEXTUAL TEACHING AND LEARNING
}

\author{
Sumiyati \\ SMP Negeri 14 Surakarta
}

Email: yatiek_solo@gmail.com

\begin{abstract}
Abstrak
Stigma negatif siswa yang menganggap IPS sebagai pembelajaran yang membosankan, antusiasme siswa, dan rendahnya minat untuk belajar merupakan persoalan klasik yang tidak pernah selesai. Strategi pembelajaran yang monoton juga menambah permasalahan menjadi semakin rumit. Penggunaan strategi pembelajaran kontektual (CTL) merupakan salah satu alternatif untuk meningkatkan motivasi dan hasil belajar IPS siswa SMP. Penelitian menggunakan metode penelitian tindakan kelas yang dilakukan di SMP Negeri 14 Surakarta yang terletak di Jalan WZ Yohannes, Jebres, Kota Surakarta. Subyek penelitian adalah siswa kelas VIII E tahun pelajaran 2015/2016 yang terdiri dari 32 orang. Teknik pengumpulan data yang dipergunakan yaitu: wawancara, observasi, angket, dan dokumentasi. Teknik analisis data yang dipergunakan adalah: teknik analisis data kualitatif model Miles \& Huberman yang terdiri dari tiga kegiatan yaitu: data reduction, data display, dan conclussion untuk data kualitatif, sedangkan analisis data kuantitatif menggunakan statistik diskriptif yaitu analisis tendensi sentral. Penerapan model pembelajaran Contetual Teaching and Learning (CTL) dapat meningkatkan motivasi belajar siswa sebesar 31,25\%. Setelah dilaksanakan tindakan siklus I skor motivasi tinggi meningkat, namun masih belum mencapai target penelitian yakni sebesar 59,38\%. Pada tindakan siklus II skor motivasi tinggi meningkat menjadi sebesar $81,25 \%$. Penerapan model pembelajaran Contetual Teaching and Learning (CTL) juga dapat meningktakan hasil belajar siswa kelas VIII E SMP Negeri 14 Surakarta pada tahun ajaran 2015/2016. Hal ini dapat diketahui dari perolehan nilai hasil belajar dari pra tindakan, yakni siswa yang tuntas belajar atau mencapai batas KKM $(>75)$ sebesar 21,87\%. Setelah dilakukan tindakan siklus I ketuntasan belajar siswa meningkat menjadi $56,25 \%$. Setelah dilakukan tindakan pada siklus II ketuntasan belajar siswa mencapai $78,12 \%$.
\end{abstract}

Kata Kunci: motivasi belajar, contextual teaching and learning 


\begin{abstract}
The negative stigma of students who consider IPS as boring learning, student enthusiasm, and low interest in learning is a classic problem that is never finished. Monotonous learning strategies also add to the problem becomes more complicated. The use of contextual learning strategy (CTL) is one of the alternatives to improve motivation and learning outcomes of junior high school students. The research used classroom action research methods conducted at SMP Negeri 14 Surakarta located at WZ Yohannes, Jebres, Kota Surakarta. The subjects of the study were students of class VIII E academic year 2015/2016 consisting of 32 people. Data collection techniques used are: interviews, observation, questionnaires, and documentation. Data analysis techniques used are: qualitative data analysis techniques Miles \& Huberman model consisting of three activities, namely: data reduction, display data, and conclusion for qualitative data, while quantitative data analysis using descriptive statistics that is the analysis of central tendency. Application of Contextual Teaching and Learning (CTL) learning model can increase student's learning motivation by $31,25 \%$. After the first cycle of action, high motivation score increased, but still not reached the target of research that is equal to 59,38\%. In action cycle II high motivation score increased to equal to $81,25 \%$. The application of Contextual Teaching and Learning (CTL) learning model can also increase the learning outcomes of the students of class VIII E SMP Negeri 14 Surakarta in the academic year 2015/2016. This can be known from the acquisition of learning result value from pre-action, that is students who complete study or reach the limit of KKM (> 75) equal to 21,87\%. After doing action cycle I learn student completeness increased to 56,25\%. After done action on cycle II mastery learn student reach $78,12 \%$.
\end{abstract}

Keyword: learning motivation, contectual teaching dan learning

\title{
Pendahuluan
}

Seiring perkembangan jaman, manusia mengalami perubahan pola hidup dari yang bersifat tradisional menjadi bersifat modern. Hal tersebut tidak terlepas dari usaha manusia yang ingin terus maju untuk meningkatkan kualitas hidup/Sumber Daya Manusia (SDM) agar lebih baik dari waktu ke waktu. Salah satu upaya meningkatkan kualitas SDM yaitu melalui pendidikan. Pendidikan adalah suatu usaha yang dilakukan secara sadar dan sengaja untuk mengubah tingkah laku manusia baik secara individu maupun kelompok untuk mendewasakan manusia melalui upaya pengajaran dan pelatihan (Sugihartono dkk, 2010: 3).

Pendidikan juga dianggap sebagai investasi masa depan karena dampaknya tidak hanya berguna bagi kehidupan saat sekarang, namun juga dirasakan pada masa yang akan datang. Kehidupan yang akan datang dapat dibentuk melalui pendidikan yang sedang dilakukan sekarang, artinya bahwa pendidikan harus dapat menyiapkan dan menjawab tantangan dan kebutuhan 
di masa depan. Tantangan dan kebutuhan hidup di masa depan diantaranya banyak dibutuhkan sumber daya manusia (SDM) yang berkualitas dan memiliki kemampuan bersaing seiring kemuajuan teknologi.

Di Indonesia pendidikan diselenggarakan pada jenjang pendidikan dari tingkat pendidikan anak usia dini sampai perguruan tinggi. Melalui pendidikan tersebut diharapkan mampu menghasilkan lulusan yang mempunyai kompetensi tinggi, khususnya di bidang akademik. Secara umum ada dua faktor yang mempengaruhi kualitas pendidikan, yaitu faktor internal dan faktor eksternal. Faktor internal biasanya berhubungan dengan sistem pendidikan yang dipakai sekarang ini, dalam hal ini terkait dinas pendidikan yang berwenang dalam menentukan kebijakan. Sedangkan faktor eksternal berupa kualitas guru baik kualitas pedagogik maupun kualitas afektif. Sebagian besar guru masih menggunakan model pembelajaran secara konvensional.

Pendidikan secara hakiki telah diakui oleh masyarakat sebagai investasi masa depan. Hal tersebut dikarenakan hasil dari proses pendidikan tidak hanya berguna saat ini, namun juga untuk waktu selanjutnya. Kehidupan yang akan datang dapat dibentuk melalui pendidikan yang sedang dilakukan sekarang, artinya bahwa pendidikan harus dapat menyiapkan dan menjawab tantangan dan kebutuhan di masa depan. Tantangan dan kebutuhan hidup di masa depan diantaranya banyak dibutuhkan sumber daya manusia (SDM) yang berkualitas dan memiliki kemampuan bersaing seiring kemuajuan teknologi.

Pembelajaran yang dilakukan di dalam kelas seharusnya mampu mengantarkan siswa untuk mencapai kompetensi dasar dan kompetensi inti. Pembelajaran yang baik adalah pembelajaran yang telah direncanakan sedemikian rupa dengan metode dan media yang mendukung. Dalam perencanaan kita perlu memperhatikan metode yang akan kita gunakan, karena keberhasilan suatu pembelajaran dapat dilihat dari seberapa aantusias dan perhatiaan siswa dalam mengikuti pembelajaran. Metode pembelajaran mempunyai peran penting dalam membangun konsentrasi atau perhatian siswa dalam belajar. Apabila metode yang digunakan tidak meenarik maka kemungkinan siswa tidak memperhatikan pelajaran sangat besar.

Hal ini dapat kita lihat dari pola pembelajaran yang sedang berlangsung saat ini, dimana guru yang tidak kaya metode pembelajaran biasanya dalam menyampaikan materi hanya menggunakan metode ceramah, diskusi, ceramah dan tanya-jawab. Di mana metode ini dianggap kurang menarik oleh siswa, 
karena bersifat monoton, kurang interaktif dan tidak menarik, sehingga kurang interaktif dan belum optimal dalam membangun konsentrasi siswa. Berkaitan dengan hal tersebut pendidikan harus memperhatikan beberapa aspek yaitu: (1) pendidikan diselenggarakan secara demokratis dan berkeadilan serta tidak diskriminatif dengan menjunjung tinggi hak asasi manusia, nilai keagamaan, nilai kultural, dan kemajuan bangsa. (2) Proses pendidikan dilaksanakan melalui tiga jalur pendidikan terdiri atas pendidikan formal, nonformal, dan informal yang dapat saling melengkapi dan memperkaya, (3) dalam lingkup kehidupan nasional pendidikan kita ditandai oleh kondisi yang bersifat multikultural, sehingga perlu memperhatikan aspek-aspek kultural bangsa Indonesia.

Pembelajaran IPS di sekolah masih menemukan banyak permasalahan baik dari sisi guru, fasilitas, peserta didik, maupun kurikulumnya. Hal tersebut bermuara pada rendahnya kualitas pembelajaran IPS di sekolah khususnya jenjang SMP yang mengimplementasikan IPS Terpadu. Pada awalnya guru-guru masih kebingungan dengan format kurikulum KTSP yang mewajibkan guru untuk memadukan konten sejarah, geografi, ekonomi, dan sosiologi. Hal ini sangat beralasan karena memang latar belakang akademik mereka yang umumnya berasal dari sejarah, geografi atau ekonomi. Berbagai pelatihan dan workshop yang telah dilakukan seperti tidak membuahkan hasil secara memuaskan, bahkan ketika kurikulum sudah akan berganti sekalipun.

Persoalan lain yang dihadapi oleh guru IPS antara lain adanya stigma negatif dari siswa yang menganggap IPS sebagai pembelajaran yang membosankan, hanya hafalan saja. Antusias siswa yang rendah dalam mengikuti pelajaran juga dapat terlihat dari sebagian siswa yang saling mengobrol tentang hal-hal di luar materi pelajaran. Sebagian dari mereka yang antusias mengikuti pelajaran, hanya saja jumlahnya yang sedikit sehingga situasi pembelajaran masih kurang kondusif. Akibatnya, materi pembelajaran tidak tersampaikan dengan baik kepada siswa. Pada waktu belajar siswa sebagian besar dipergunakan untuk mendengarkan ceramah dan dan kegiatan memahami materi pelajaran dengan membaca buku teks pelajaran, sehingga tidak sedikit para siswa yang merasa bosan. Terlebih lagi ketika guru memberi pertanyaan kepada siswa, banyak diantara mereka yang tidak dapat menjawab pertanyaan dengan baik dan benar. 
Seiring berjalannya waktu hal ini menjadi salah satu penyebab kurang tertariknya siswa terhadap mata pelajaran IPS. Dampak dari hal tersebut kebanyakan siswa kurang mencermati materi pelajaran yang disampaikan oleh guru, serta hasil belajar yang rendat - ${ }_{81}$ dahnya hasil belajar siswa bukan hanya pada aspek kognitif saja, tetapi juga nampak pada aspek-aspek afektif.

Pembelajaran IPS di kelas VIII E SMP 14 Surakarta pada umumnya masih memprihatinkan. Sebagian besar siswa mendengarkan ceramah dari guru. Kegiatan memahami materi pelajaran dilakukan dengan membaca buku teks pelajaran serta LKS. Oleh karenanya tidak sedikit para siswa yang merasa bosan terhadap mata pelajaran tersebut. Terlebih lagi ketika guru memberi pertanyaan kepada siswa, banyak diantara mereka yang tidak dapat menjawab pertanyaan dengan baik dan benar. Seiring berjalannya waktu hal ini menjadi salah satu penyebab kurang tertariknya siswa terhadap mata pelajaran IPS. Dampak yang ditimbulkan yaitu terlihat siswa kurang mencermati materi pelajaran yang disampaikan oleh guru, serta hasil belajar yang rendah. Rendahnya motivasi belajar IPS pada siswa kelas VIII E SMP 14 Surakarta dapat digambarkan dalam tabel berikut:

Tabel. 1. Motivasi Belajar Siswa Kelas VIII E

\begin{tabular}{lcc}
\hline \multicolumn{1}{c}{ Proses Pembelajaran } & Jumlah Siswa & Persentase \\
\hline Motivasi Belajar Rendah & 26 & $81,25 \%$ \\
Siswa mencapai KKM & 11 & $35 \%$ \\
Siswa belum mencapai KKM & 21 & $65 \%$ \\
& & \\
\hline (Sumber : Dokumen Kelas ) & &
\end{tabular}

\section{Urgensi Motivasi dalam Pembelajaran IPS}

Ilmu Pengetahuan Sosial (IPS) diartikan sebagai studi tentang manusia yang dipelajari oleh siswa sekolah dasar dan menengah. Keberadaan IPS dalam kurikulum pendidikan di Indonesia tidak dapat dilepaskan dari perkembangan social studies di Amerika Serikat. Di negeri asalnya, yaitu Amerika Serikat, social studies merupakan sebuah kajian, bukan sebuah disiplin ilmu. Oleh karenanya, pendekatan yang dipergunakan adalah interdisipliner dengan menggunakan ilmu sosial sebagai inti keilmuannya. National Comission for Social Studies (Numan Sumantri, 2001: 91) menyatakan bahwa: 
Social studies is the integrated study of the social sciences and humanities to promote civic competence. Within the school program, social studies provides coordinated, systematic study drawing upon such disciplines as anthropology, archeology, economics, geography, history, law, philosophy, political science, psychology, religion, and sociology as well as appropriate content from humanities, mathematics, and natural sciences.

Pendidikan IPS merupakan pendidikan yang mengembangkan pengetahuan, sikap dan ketrampilan sosial dalam rangka membentuk pribadi warga negara yang baik dan merupakan program pendidikan sosial pada jalur pendidikan sekolah (Udin S Wiranatakusuma, 2004: 112). Pembelajaran IPS Terpadu dirancang secara sistematis tujuannya untuk meningkatkan pemahaman dan penanaman sikap pada diri siswa. Dalam proses pembelajaran banyak melibatkan peran aktif antara guru dengan siswa, sesuai dengan tujuan pembelajaran yang disampaikan oleh guru melalui materi, metode, media dan evaluasi pembelajaran.

Esensi tujuan pembelajaran IPS adalah perubahan perilaku dan tingkah laku positif siswa sesuai dengan budaya, nilai, kebiasaan dan tradisi yang berlaku di dalam masyarakatnya. Dalam penelitian ini lebih mengarah pada tercapaianya pola sikap pada diri siswa untuk saling menghormati, menghargai, dan kemampuan bekerjasama dengan orang lain. John Jarolimek (1977: 3-4) menulis sebagai berikut:

Social studies has as its particular mission the task helping young people to develop competencies that enable them to deal with, and to some extent manage, the physical and social forces of the world in which they live. Such competencies make to possible for pupils to shape their lives in harmony with those forces. Social studies education should also provide young people with a feeling of hope in the future and confidence in their ability to solve social problems.

Gagasan tersebut menyiratkan misi penting IPS untuk mengembangkan kompetensi warga negara dalam kehidupan di masyarakat yang semakin kompleks. Hal tersebut sejalan dengan pandangan Sardiman (2010: 151) yang menyatakan bahwa dalam pendidikan IPS siswa diarahkan, dibimbing dan dibelajarkan agar menjadi warga negara dan warga dunia yang baik dengan memiliki kepekaan, kemampuan memahami, menelaah dan ikut memecahkan masalah-masalah sosial kemasyarakatan dan kebangsaan serta mewarisi dan mengembangkan nilai-nilai luhur budaya bangsa. NCCS (Arthur Ellis, 1998: 2) menyatakan bahwa: 
The primary purpose of social studies is to help young people develop the ability to make informed and reasoned decisions for the public goods as citizens of a culturally diverse, democratic society in an interdependent world.

IPS mempunyai misi yang sangat herat yaitu membina warga masyarakat agar mampu menyelarakan kehidu 83 ya berdasarkan kekuatan-kekuatan fisik dan sosial, serta mampu melahirkan kemampuan untuk memecahkan permasalahan sosial yang dihadapinya. Pengembangan kemampuan peserta didik sebagai warga masyarakat yang demokratis, kritis, peduli, dan sikap sosial tinggi harus dibarengi dengan upaya pengembangan nilai-nilai kehidupan yang kondusif dalam rangka terciptanya masyarakat yang demokratis dan dinamis. Motivasi belajar mempunyai peranan yang sangat penting yang menentukan kualitas pembelajaran di dalam kelas. Dalam konteks tersebut guru IPS mempunyai tantangan yang sangat berat untuk meningkatkan motivasi siswa dalam belajar IPS.

Sardiman (2007:84) mengatakan bahwa motivation is an essentials condition of learning. Hasil belajar akan optimal jika ada motivasi yang tinggi, semakin tinggi motivasi, maka keberhasilan dalam mencapai tujuan belajar juga akan semakin mudah. Adanya motivasi juga dapat meningkatkan intensitas kerja keras siswa dalam belajar.

Tiga fungsi motivasi, yaitu:

1) Mendorong manusia untuk berbuat. Motivasi dalam hal ini merupakan motor penggerak dari setiap kegiatan yang akan dikerjakan.

2) Menentukan arah perbuatan, yakni kearah tujuan yang akan dicapai. Motivasi dapat memberikan arah dan kegiatan yang harus dikerjakan sesuai dengan tujuan yang hendak dicapai.

3) Menyelesaikan perbuatan, yakni menentukan perbuatan-perbuatan apa yang harus dikerjakan yang serasi guna mencapai tujuan, dengan meninggalkan perbuatan yang tidak bermanfaat bagi tujuan tersebut.

Soemarsono (2007:20) menyatakan bahwa motivasi dapat berfungsi sebagai pendorong usaha dan pencapaian prestasi. Seseorang melakukan usaha karena adanya motivasi. Adanya motivasi juga baik dalam belajar akan menunjukkan hasil yang baik. Salah satu strategi guru dalam upaya menumbuhkan dan meningkatkan motivasi siswa adalah dengan menerapkan strategi pembelajaran yang bervariasi sehingga mampu menumbuhkan pembelajaran yang kreatif dan menyenangkan. 


\section{Contextual Teaching and Learning (CTL)}

U.S Department of Education and the National School to Work Office Menyatakan bahwa pembelajaran kontekstual (Contextual Teaching and Learning) merupakan suatu konsepsi yang membantu guru mengaitkan isi pelajaran dengan situasi dunia nyata dan memotivasi siswa membuat hubungan antara pengetahuan dengan penerapannya dalam kehidupan mereka sebagai anggota keluarga, warganegara, dan tenaga kerja (Nurhadi, 2002:7). CTL melibatkan tujuh komponen utama pembelajaran efektif yakni konstruktivisme (constructivism), bertanya (questioning), menemukan (inquiry), masyarakat belajar (learning community), pemodelan (modelling) dan penilaian sebenarnya (authentic assesment).

Tugas guru dalam pembelajaran kontekstual adalah membantu siswa dalam meraih tujuannya, artinya guru lebih fokus pada urusan strategi daripada memberi informasi. Guru dalam hal ini bertugas sebagai menejer yag mengelola kelas sebagai sebuah tim yang bekerja untuk menemukan sesuatu yang baru. Proses pembelajaran lebih diwarnai student centered ketimbang teacher centered.

Strategi pembelajaran melalui pendekatan kontekstual (contextual teaching and learning) merupakan konsep belajar yang membantu guru untuk mengkorelasikan materi yang diajarkan dengan realitas dunia nyata, serta mendorong murid membangun interaksi antara pengetahuan yang dimilikinya dengan penerapannya dalam kehidupan mereka sebagai anggota keluarga dan masyarakat. Dalam kaitan ini siswa dapat menyadari sepenuhnya apa makna belajar, manfaatnya, bagaimana upaya untuk mencapainya dan dapat memahami bahwa yang mereka pelajari bermanfaat bagi hidupnya nanti, sehingga mereka akan memposisikan diri sebagai diri mereka sendiri yang membutuhkan bekal hidupnya dan berupaya keras untuk meraihnya.

Lima bentuk pembelajaran yang penting dalam pendekatan kontekstual yaitu, mengaitkan (relating), mengalami (experiencing), menerapkan (applying), bekerja sama (cooperating), dan mentransfer (transferring). Langkah-langkah yang dilaksanakan oleh guru dalam pembelajaran CTL sebagai berikut (Nurhadi, 2002: 9): 
1) Mengembangkan penilaian bahwa anak akan belajar lebih bermakna dengan cara bekerja sendiri dan mengkonstruksi sendiri pengetahuan dan keterampilan barunya;

2) Melaksanakan sejauh mungkin kegiatan inquiry untuk semua topic;

3) Mengembangkan sifat ingin tahu siswa dengan bertanya;

4) Menciptakan masyarakat belajar ( belajar dalam kelompok);

5) Menghadirkan model sebagai contoh pembelajaran;

6) Melakukan refleksi di akhir pertemuan;

7) Melakukan penilaian autentik.

\section{Motivasi Belajar IPS}

Oemar Halamik (1992: 173) menyatakan bahwa motivasi merupakan perubahan energi dalam diri (pribadi) seseorang yang ditandai dengan timbulnya perasaan dan reaksi untuk mencapai tujuan. Sardiman (2007: 73) menyatakan bahwa motivasi adalah perubahan energi dalam diri seseorangyang ditandai dengan munculnya felling dan didahului dengan tanggapan terhadap adanya tujuan. Menurut Mulyasa (2003:112) motivasi adalah tenaga pendorong atau penarik yang menyebabkan adanya tingkah laku ke arah suatu tujuan tertentu. Peserta didik akan bersungguh-sungguh karena memiliki motivasi yang tinggi. Seorang siswa akan belajar bila ada faktor pendorongnya yang disebut motivasi.

Dimyati dan Mudjiono (2002:80) mengutip pendapat Koeswara mengatakan bahwa siswa belajar karena didorong kekuatan mental, kekuatan mental itu berupa keinginan dan perhatian, kemauan, cita-cita di dalam diri seorang terkadang adanya keinginan yang mengaktifkan, menggerakkan, menyalurkan dan mengarahkan sikap dan perilaku individu dalam belajar. Jadi dapat disimpulkan motivasi belajar adalah keseluruhan daya penggerak didalam diri siswa yang menimbulkan kegiatan belajar menjamin kelangsungan dan memberikan arah pada kegiatan belajar sehingga tujuan yang dikehendaki dapat tercapai. Dalam motivasi belajar dorongan merupakan kekuatan mental untuk melakukan kegiatan dalam rangka pemenuhan harapan dan dorongan dalam hal ini adalah pencapaian tujuan.

Hamzah B. Uno (2007:27) berpendapat bahwa ada beberapa peranan penting motivasi dalam belajar dan pembelajaran, antara lain: (1)menentukan hal-hal yang dapat dijadikan penguat belajar, (2) memperluas tujuan belajar 
yang hendak dicapai, (3) menentukan ragam kendali terhadap rangsangan belajar, (4) menentukan ketekunan belajar. Sardiman (2007:84) mengatakan bahwa belajar sangat memerlukan motivasi. Motivation is an essentials condition of learning. Hasil belajar akan optimal jika ada motivasi yang tingg. Semakin tinggi motivasi, maka keberhasilan dalam mencapai tujuan belajar juga akan semakin mudah. Dengan adanya motivasi juga dapat meningkatkan intensitas kerja keras siswa dalam belajar. Selain itu Sardiman (2007:85) juga mengemukakan tiga fungsi motivasi, yaitu:

1) Mendorong manusia untuk berbuat. Motivasi dalam hal ini merupakan motor penggerak dari setiap kegiatan yang akan dikerjakan;

2) Menentukan arah perbuatan, yakni kearah tujuan yang akan dicapai. Motivasi dapat memberikan arah dan kegiatan yang harus dikerjakan sesuai dengan tujuan yang hendak dicapai;

3) Menyelesaikan perbuatan, yakni menentukan perbuatan-perbuatan apa yang harus dikerjakan yang serasi guna mencapai tujuan, dengan meninggalkan perbuatan yang tidak bermanfaat bagi tujuan tersebut.

Motivasi dapat berfungsi sebagai pendorong usaha dan pencapaian prestasi. Seseorang melakukan usaha karena adanya motivasi. Adanya motivasi juga baik dalam belajar akan menunjukkan hasil yang baik (Soemarsono, 2007:20). Ada berbagai strategi yang biasa digunakan untuk memberikan stimulus siswa agar produktif dalam belajar. Salah satunya adalah dengan mengkaitkan dengan kondisi lingkungan, yang berisi kondisi lingkungan sportif, kondisi tingkat kesukaran, kondisi belajar yang bermakna, dan penggunaan strategi yang bermakna.

Hamzah B Uno (2007) memberikan beberapa catatan berisi cara-cara yang dapat dipergunakan guru untuk memotivasi siswa dalam belajar antara lain: 1) Pernyataan penghargaan secara verbal; 2) Menggunakan nilai ulangan sebagai pemacu keberhasilan; 3) Menimbulkan rasa ingin tahu; 4) Memunculkan sesuatu yang tidak diduga oleh siswa; 5) Menggunakan materi yang dikenal siswa sebagai contoh dalam belajar; 6) Menggunakan kaitan yang unik dan tak terduga untuk menerapkan suatu konsep dan prinsip yang telah dipahami; 7) Menggunakan simulasi dan permainan; 8) Memberi kesempatan pada siswa untuk memperlihatkan kemahirannya di depan umum; dan lainlain. 


\section{Metode Penelitian}

Jenis penelitian yang dipergunakan adalah penelitian tindakan kelas (classroom action research). Kemmis \& Taggart (1988: 5) menyatakan bahwa action research is a form of colective self-reflective enquiry by participants in social situation in order to improve the rationality and justice of their own social or educational practices, as well as their undertanding of these practices and situations in which these practices are carried out.

Penelitian tindakan kelas merupakan bentuk tindakan terkendali yang dilakukan guru maupun kolaboratif dengan pihak lain, untuk mengatasi permasalahan riil yang ada dalam proses pembelajaran di kelas. Untuk itu guru harus segera mencari solusi agar permasalahan dalam pembelajaran dapat segera teratasi. Penelitian tindakan kelas juga mengutamakan perbaikan kualitas pendidikan dengan melakukan inovasi-inovasi pembelajaran baik dalam model ataupun metodenya. Penelitian tindakan kelas yang dilaksanakan mengacu pada classroom action research model Kemmis \& Taggart (1988) dengan tiga langkah kegiatan yaitu: planning, acting \& observing dan reflecting. Bagan kegiatan penelitian digambarkan sebagai berikut: 
Gambar 1. Bagan Kegiatan PTK Mode Kemmis \& Taggart

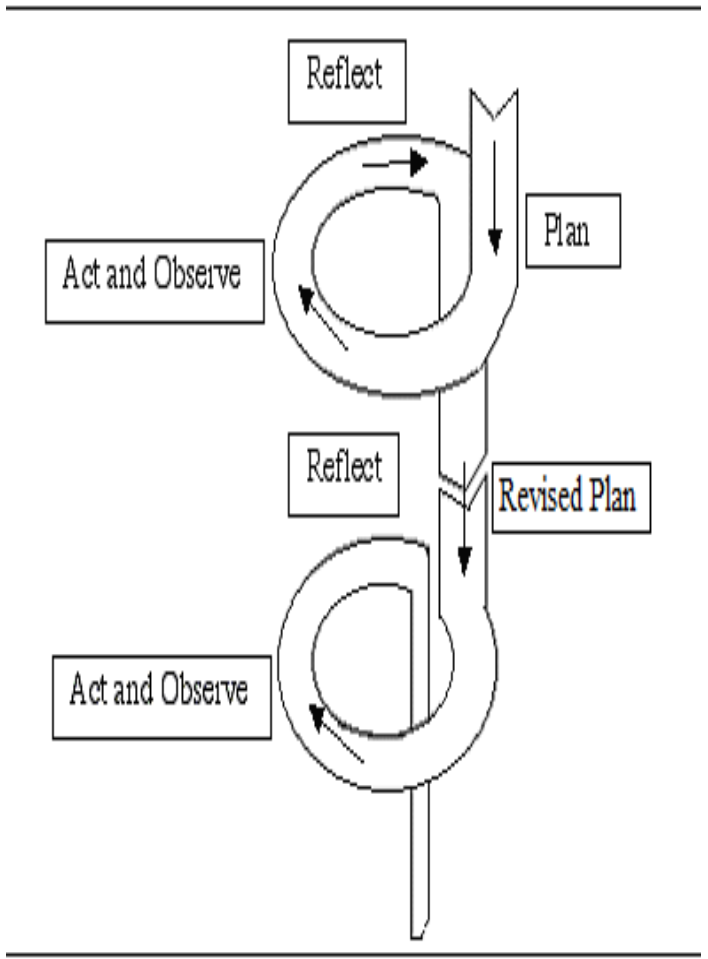

Sumber: Kemmis \& Taggart (1988)

Penelitian dilakukan di SMP Negeri 14 Surakarta yang terletak di Jalan WZ Yohannes, Jebres, Kota Surakarta. Subyek penelitian adalah siswa kelas VIII E tahun pelajaran 2015/2016 yang terdiri dari 32 orang. Pemilihan subjek penelitian dilakukan dengan pertimbangan bahwa masalah yang telah dirumuskan muncul di kelas VIII E. Pemberian tindakan dilakukan dalam dua siklus, siklus pertama dilaksanakan pada tanggal 11 November 2015 dengan dua kali pertemuan, sedangkan siklus kedua dengan dua kali pertemuan juga dilaksanakan pada tanggal 18 November 2015.

Teknik pengumpulan data yang dipergunakan yaitu: wawancara, observasi, angket, dan dokumentasi. Sedangkan teknik analisis data yang dipergunakan adalah teknik analisis data kualitatif model Miles \& Huberman yang terdiri dari tiga kegiatan yaitu: data reduction, data display, dan conclussion untuk data kualitatif, sedangkan analisis data kuantitatif menggunakan statistik diskriptif yaitu analisis tendensi sentral. 
Gambar 2`. Desain analisis data interaktif Model Miles \& Huberman

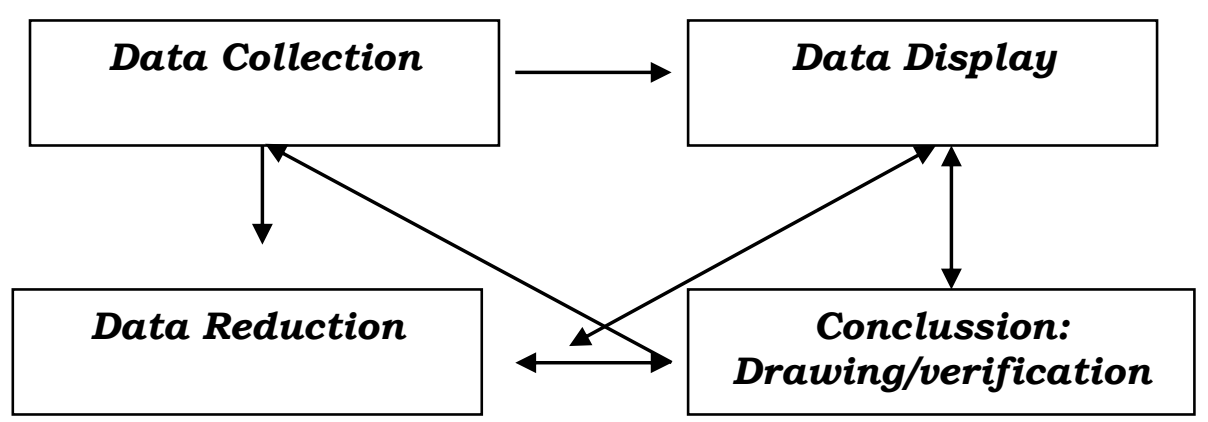

Sumber: Sugiyono(2008)

Dalam setiap tahapan siklus terdiri dari :

a. Perencanaan

b. Tindakan

c. Observasi

d. Refleksi

Keempat tahapan siklus dilaksanakan dalam bentuk tahapan yang dilaksanakan dalam setiap kali proses pembelajaran dan mencerminkan kondisi tertentu baik aspek permasalahan maupun maupun hasil belajar yang terdiri dari :

\section{Perencanaan Tindakan}

\section{a. Penemuan masalah}

Sebelum melakukan penelitian maka peneliti melakukan pra survei untuk menemukan masalah melalui observasi, wawancara dan diskusi melalui pihak-pihak yang berkaitan dengan permasalahan. b. Pemilihan masalah.

Pemilihan masalah yang terjadi dilokasi penelitian cukup banyak sehingga peneliti menentukan skala prioritas pemecahan masalah.

Diantara berbagai masalah yang ada maka peneliti akan mengungkapkan aspek sebagai berikut :

1). Kemampuan guru dalam melaksanakan pembelajaran

2). Kemampuan siswa dalam menerima materi pelajaran.

3). Sikap siswa dan motivasi dalam mengikuti pembelajaran. 
c. Penajaman Masalah.

Dari prioritas masalah yang dipilih maka peneliti akan menerima dan mempertajam masalah menjadi indikator untuk merumuskan hipotesis tindakan.

d. Rancangan pemecahan masalah.

Rancangan pemecahan masalah meliputi langkah-langkah sebagai berikut :

1). Peneliti membuat rencana tindakan dan mendiskusikan dengan kolaborator untuk melaksanakan tindakan.

2). Melakukan tindakan yang direncanakan oleh peneliti yang telah disepakati oleh kolaborator.

3). Melakukan diskusi dengan kolaborator untuk merefleksikan tindakan yang dilakukan dikelas untuk melakukan perbaikan pada siklus selanjutnya.

2. Pelaksanaan Tindakan

Rencana tindakan yang dibuat bersama kolaborator menjadi pedoman untuk melaksanakan tindakan, rencana tersebut bersifat pleksibel sehingga dalam penerapanya dapat disesuaikan dengan situasi dan kondisi yang ada.

3. Observasi

Selama tindakan yang dilakukan di kelas maka diobservasi sehingga hal-hal yang terjadi selama pelaksanaan tindakan dapat mencatat mulai dari persiapan hingga akhir kegiatan.

4. Refleksi

Kegiatan refleksi dilaksanakan dengan cara diskusi dengan pihak-pihak yang terkait setelah tindakan dilaksanakan, sehingga ditemukan permasalahan yang dapat ditarik kesimpulannya apakah tindakan telah sesuai dengan tujuan atau tindakan yang harus di direvisi untuk kegiatan yang akan datang agar lebih fokus 


\section{Hasil Penelitian dan Pembahasan}

Siklus pertama dilaksanakan dengan mengacu pada Rencana Kegiatan Pembelajaran (RPP) dengan materi permasalahan kependudukan dan dampaknya terhadap pembangunan nasional. Pelaksaan dimulai pada pukul 09.40 - 11.00 WIB. Secara garis besar rangkaian kegiatan pembelajaran siklus I dapat digambarkan sebagai berikut:

1. Guru membuka pelajaran dengan salam dan menanyakan kabar siswa, kemudian menyampaikan kompetensi (tujuan yang akan dicapai dan rencana kegiatan pembelajaran saat itu, guru membuka pelajaran dengan menayangkan gambar permasalahan kependudukan di Indonesia.

2. Guru memberikan kesempatan kepada siswa untuk memahami gambar yang ditampilkan (konstruktivisme)

3. Guru membantu siswa dalam memahami materi yang diberikan, sehingga pada siswa terdapat proses perpindahan dari pengamatan menjadi pemahaman berdasarkan pengalaman masing-masing siswa (Inquiry)

4. Adanya kegiatan tanya jawab antara guru dan siswa selama proses pembelajaran (Questioning)

5. Guru membagi siswa menjadi 5-6 kelompok belajar, kemudian guru membagikan LKS kepada masing-masing kelompok untuk didiskusikan. Guru membantu siswa dalam membangun pemahaman melalui pengamatan awal terhadap topik/materi yang berkaitan dengan kehidupan nyata mereka, untuk didiskusikan secara kelompok (Learning Community )

6. Guru mempersilahkan masing-masing kelompok untuk mempresentasikan hasil diskusi secara bergilir (modeling)

7. Guru melakukan reflesi atau membuat rangkuman hasil pembelajaran dengan melibatkan siswa (reflecion).

Pada pertemuan kedua guru dan 89 olaborator menyajikan tes untuk mengukur hasil belajar dan sekaligus membagikan angket untuk mengukur motivasi belajar siswa dengan menggunakan CTL. Pemberian tindakan pada siklus pertama dianggap telah berhasil meningkatkan motivasi belajar siswa yang ditunjukkan dengan berbagai indikator yaitu: keserusan siswa dalam berdiskusi dan bersungguh-sungguh dalam mengerjakan tugas, keaktifan siswa untuk bertanya tentang hal-hal yang belum diketahui, serta munculnya 
JIPSINDO No. 1, Volume 4, Maret 2017

keberanian siswa utuk menyampaikan pendapat dan gagasan di depan temantemannya.

Tabel 2. Motivasi Belajar Siswa Siklus I

\begin{tabular}{ccc}
\hline Kategori & Frekuensi (siswa) & \% \\
\hline Tinggi & 19 & 59,38 \\
Sedang & 5 & 15,62 \\
Rendah & 8 & 25 \\
Jumlah & $\mathbf{3 1}$ & $\mathbf{1 0 0}$ \\
\hline
\end{tabular}

Sumber: Data Primer yang diolah

Tes formatif siklus 1 diketahui bahwa terdapat peningkatan hasil belajar siswa yang ditunjukkan dengan adanya peningkatan jumlah siswa yang mencapai KKM. Pencapaian keberhasilan belajar siswa diketahui sebanyak lebih dari 50\% dari 32 siswa tuntas belajar atau mencapai batas KKM. Hasil belajar siswa dalam siklus I dapat digambarkan dalam tabel berikut ini.

Tabel 3. Hasil Belajar Siswa Siklus I

\begin{tabular}{ccccc}
\hline \multirow{2}{*}{ No. } & \multirow{2}{*}{ Hasil Belajar } & \multirow{2}{*}{ Keterangan } & \multicolumn{2}{c}{ Jumlah } \\
\cline { 4 - 5 } 1 & Nilai dibawah 75 & Belum Tuntas & 14 & 43,75 \\
2 & Nilai 75 ke atas & Tuntas & 18 & 56,25 \\
& Jumlah & & $\mathbf{3 2}$ & $\mathbf{1 0 0}$
\end{tabular}

\section{Sumber: Data Primer yang diolah}

Dalam kegiatan refleksi tim peneliti melakukan diskusi bersama dengan para observer untuk mengevaluasi kekurangan pelaksanaan siklus I, keberhasilan yang telah dicapai serta rencana tindak lanjut untuk siklus berikutnya.

Secara umum hasil refleksi dapat disajikan sebagai berikut:

\begin{tabular}{|c|c|c|}
\hline Keberhasilan & Kekurangan & Rencana Perbaikan: \\
\hline $\begin{array}{l}\text { Motivasi belajar siswa } \\
\text { pada kategori tinggi } \\
\text { meningkat sebesar } \\
28,13 \% \text {, dari awal pra } \\
\text { siklus sebesar }\end{array}$ & $\begin{array}{l}\text { Motivasi } \\
\text { siswa pada kategori } \\
\text { tinggi mengalami } \\
\text { peningkatan sebesar } \\
28,13 \% \text {, dari pra }\end{array}$ & $\begin{array}{l}\text { a. Menambah } \\
\text { referensi/sumber } \\
\text { materi pembelajaran, } \\
\text { agar siswa lebih } \\
\text { mudah menerima } \\
\text { materi melalui model }\end{array}$ \\
\hline
\end{tabular}




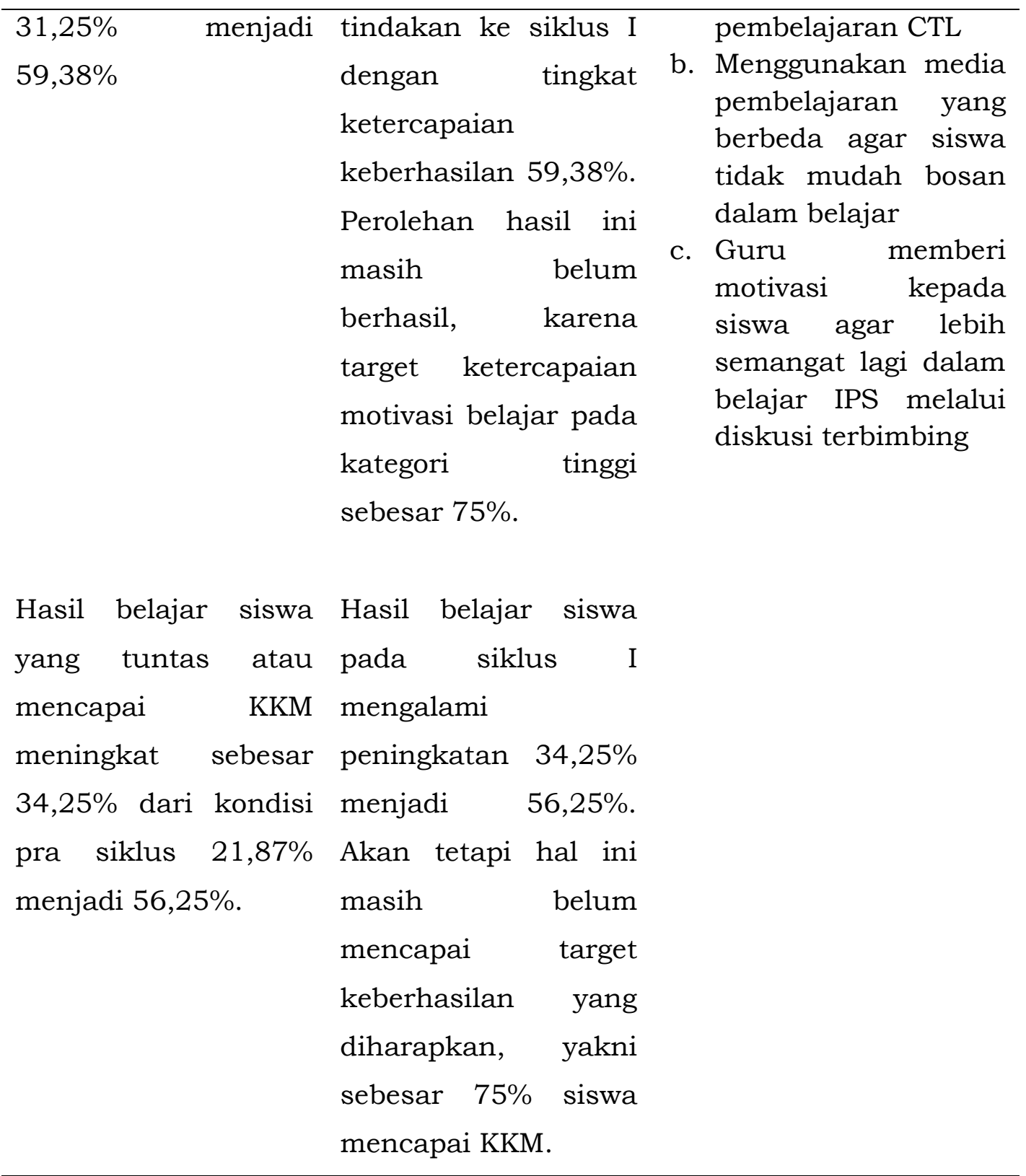

Setelah diperoleh hasil analisis dan refleksi pada siklus I, pada dasarnya diketahui peningkatan hasil yang diperoleh dari kondisi awal sebelum diberikan tindakan sampai tindakan siklus I. akan tetapi dari adanya peningkatan yang didapat, menunjukkan kurang tercapainya target keberhasilan karena adanya kekurangan dan kelemahan pembelajaran yang diterapkan pada siklus I. Untuk itu upaya-upaya perbaikan dilakukan pada siklus II guna tercapainya target penelitian. Dalam siklus II ini pelaksanaan tindakan dilakukan sebanyak 2 kali pertemuan, yakni pertemuan pertama pada 13 November 2015 dan pertemuan kedua pada 18 November 2015, dengan masing-masing pertemuan dilaksanakan selama $2 \times 40$ menit (2 jam pelajaran). Pertemuan pertama 
pelaksanaan pembelajaran mengacu pada Rencana Kegiatan Pembelajaran (RPP) dengan materi permasalahan kependudukan dan dampaknya terhadap pembangunan nasional. Pelaksaan dimulai pada pukul 09.40 - 11.00 WIB. Berikut rangkaian kegiatan selama pembelajaran:

1. Guru membuka pelajaran dengan salam dan menanyakan kabar siswa

2. Guru menyampaikan kompetensi (tujuan yang akan dicapai dan rencana kegiatan)

3. Guru membuka pelajaran dengan menayangkan gambar permasalahan kependudukan di Indonesia

Konstruktivisme (Membangun pemahaman)

4. Guru memberikan kesempatan kepada siswa untuk memahami gambar yang ditampilkan.

Inquiry (Pencarian/penemuan)

5. Guru membantu siswa dalam memahami materi yang diberikan, sehingga pada siswa terdapat proses perpindahan dari pengamatan menjadi pemahaman berdasarkan pengalaman masing-masing siswa.

6. Questioning (Tanya jawab)

7. Adanya kegiatan tanya jawab antara guru dan siswa selama proses pembelajaran.

Learning Community (Adanya komunitas belajar)

8. Guru membagi siswa menjadi 5-6 kelompok belajar, kemudian guru membagikan LKS kepada masing-masing kelompok untuk didiskusikan. Guru membantu siswa dalam membangun pemahaman melalui pengamatan awal terhadap topik/materi yang berkaitan dengan kehidupan nyata mereka, untuk didiskusikan secara kelompok.

Modeling (Pemodelan)

9. Guru mempersilahkan masing-masing kelompok untuk mempresentasikan hasil diskusi secara bergilir.

Reflection (refleksi)

10.Guru melakukan reflesi atau membuat rangkuman hasil pembelajaran dengan melibatkan siswa

Selama siklus II pembelajaran CTL yang dilaksanakan berjalan dengan lebih baik, dimana kegiatan di kelas berjalan lebih kondusif dengan menggunakan media pembelajaran yang lebih sesuai. Penyajian gambar yang lebih menarik serta kontekstual menjadikan siswa lebih antusias dalam 
mengikuti kegiatan pembelajaran. Suasana diskusi menjadi lebih hindup dimana interaksi antar siswa berjalan dengan sangat baik. Presentasi juga menjadi ajang bagi terjadinya diskusi yang lebih hidup dan kontruktif. Dalam siklus II motivasi siswa meningkat secara keseluruhan yang dapat dilihat dari sajian tabel berikut.

Tabel 4. Motivasi siswa dalam siklus II

\begin{tabular}{ccc}
\hline Kategori & Frekuensi (siswa) & \% \\
\hline Tinggi & 26 & 81,25 \\
Sedang & 3 & 9,37 \\
Rendah & 3 & 9,37 \\
Jumlah & $\mathbf{3 2}$ & $\mathbf{1 0 0}$ \\
\hline
\end{tabular}

Sumber: data primer yang diolah

Pada tes formatif siklus II telah diketahui bahwa terdapat banyak siswa yang tuntas belajar atau mencapai batas KKM yang ditentukan. Dari keseluruhan siswa yakni sebanyak 32 siswa, diperoleh hasil post tes siklus II yang memuaskan. Berikut ini hasil perolehan nilai post tes siklus II siswa kelas VIII E.

Tabel 5. Hasil Belajar Siswa dalam Siklus II

\begin{tabular}{rrrrr}
\hline \multirow{2}{*}{ No. } & \multirow{2}{*}{ Hasil Belajar } & Keterangan & \multicolumn{2}{c}{ Jumlah } \\
\cline { 4 - 5 } & & Siswa & $\%$ \\
\hline 1 & Nilai dibawah 75 & Belum Tuntas & 7 & 21,87 \\
2 & Nilai 75 ke atas & Tuntas & 25 & 78,12 \\
& Jumlah & & $\mathbf{3 2}$ & $\mathbf{1 0 0}$ \\
\hline
\end{tabular}

Sumber: Data Primer yang diolah

Refleksi yang telah dilaksanakan oleh tim peneliti sepakat untuk menghentikan kegiatan penelitian pada siklus II karena dianggap telah berhasil meningkatkan motivasi dan prestasi belajar. Ketuntasan sebesar $78 \%$ siswa dianggap telah berhasil dengan baik. Peningkatan motivasi belajar yang 
signifikan juga dianggap sebagai keberhasilan indikator penelitian yang dilakukan.

Secara garis besar keberhasilan CTL dalam meningkatkan motivasi dan hasil belajar siswa terletak pada upaya meningkatkan fokus dan perhatian siswa melalui penggunaaan bahan ajar yang kontekstual dan dekat dengan lingkungan siswa. Peningkatan motivasi belajar melalui penerapan CTL dalam dua siklus dapat digambarkan sebagai berikut:

Gambar 3. Histogram Peningkatan motivasi belajar

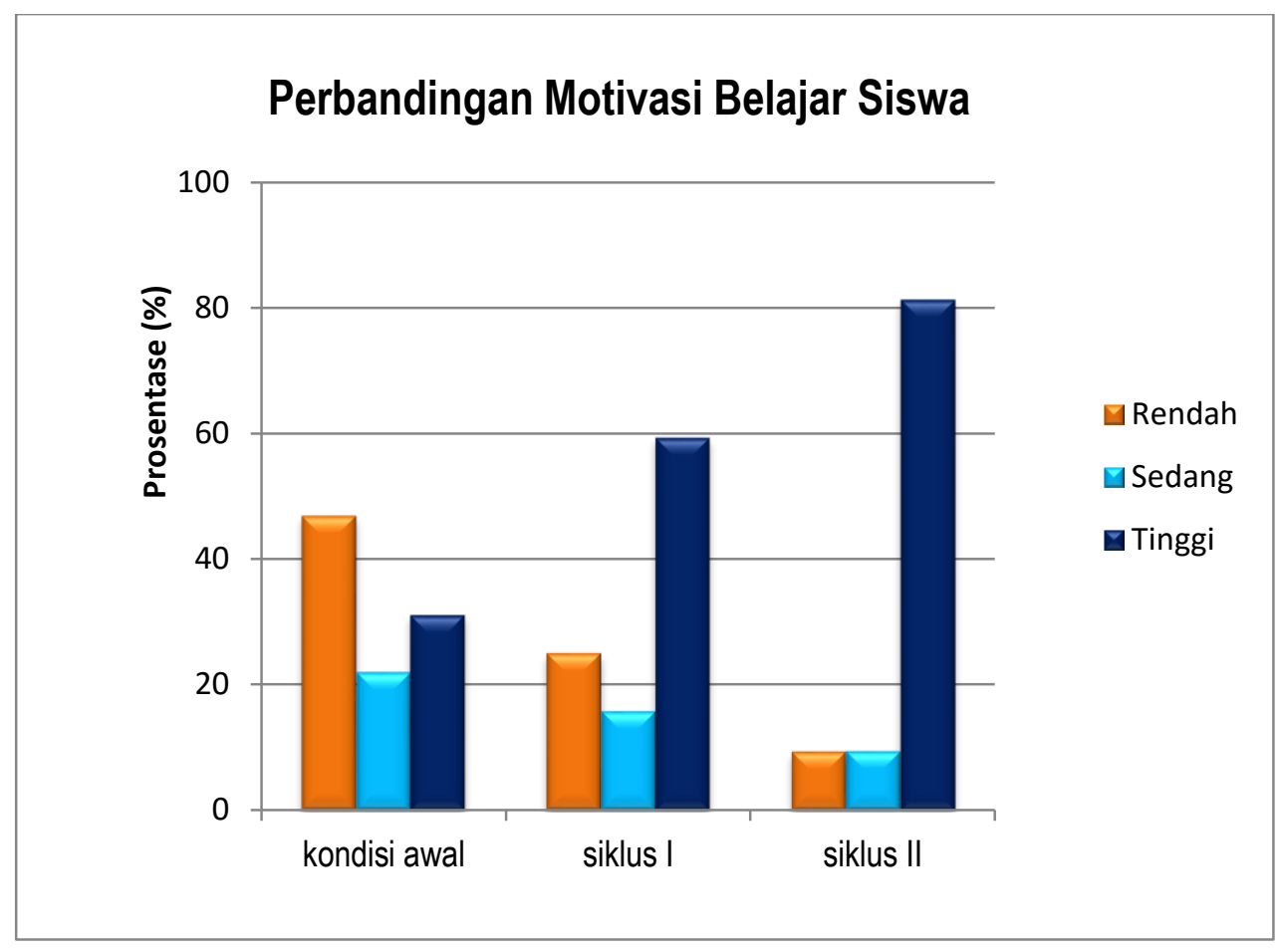

Perubahan strategi pembelajaran yang dilakukan oleh tim peneliti juga membawa peningkatan terhadap prestasi belajar siswa. Pembelajaran kontekstual dimana siswa mengkonstruk materi pembelajaran secara mandiri ternyata meningkatkan pemahaman siswa. Dengan data prosentase pada siklus II tinggi yaitu $80 \%$, yang sebelumnya di siklus I sebesar $60 \%$. Peningkatan motivasi belajar yang signifikan juga dianggap sebagai keberhasilan indikator penelitian yang dilakukan. keberhasilan CTL dalam meningkatkan motivasi dan hasil belajar siswa terletak pada upaya meningkatkan fokus dan perhatian siswa melalui penggunaaan bahan ajar yang kontekstual dan dekat dengan lingkungan siswa

Sajian bahan ajar yang mengguna-kan fenomena setempat dan hadir dalam kehidupan sehari-hari (loco centris) membawa pemahaman yang 
komprehensif dan memperluas wawasan siswa dalam memahami realitas local dalam tataran yang lebih luas. Secara umum gambaran capaian hasil belajar dalam penelitian ini disajikan dalam gambar berikut.

Gambar 4. Histogram hasil belajar siswa

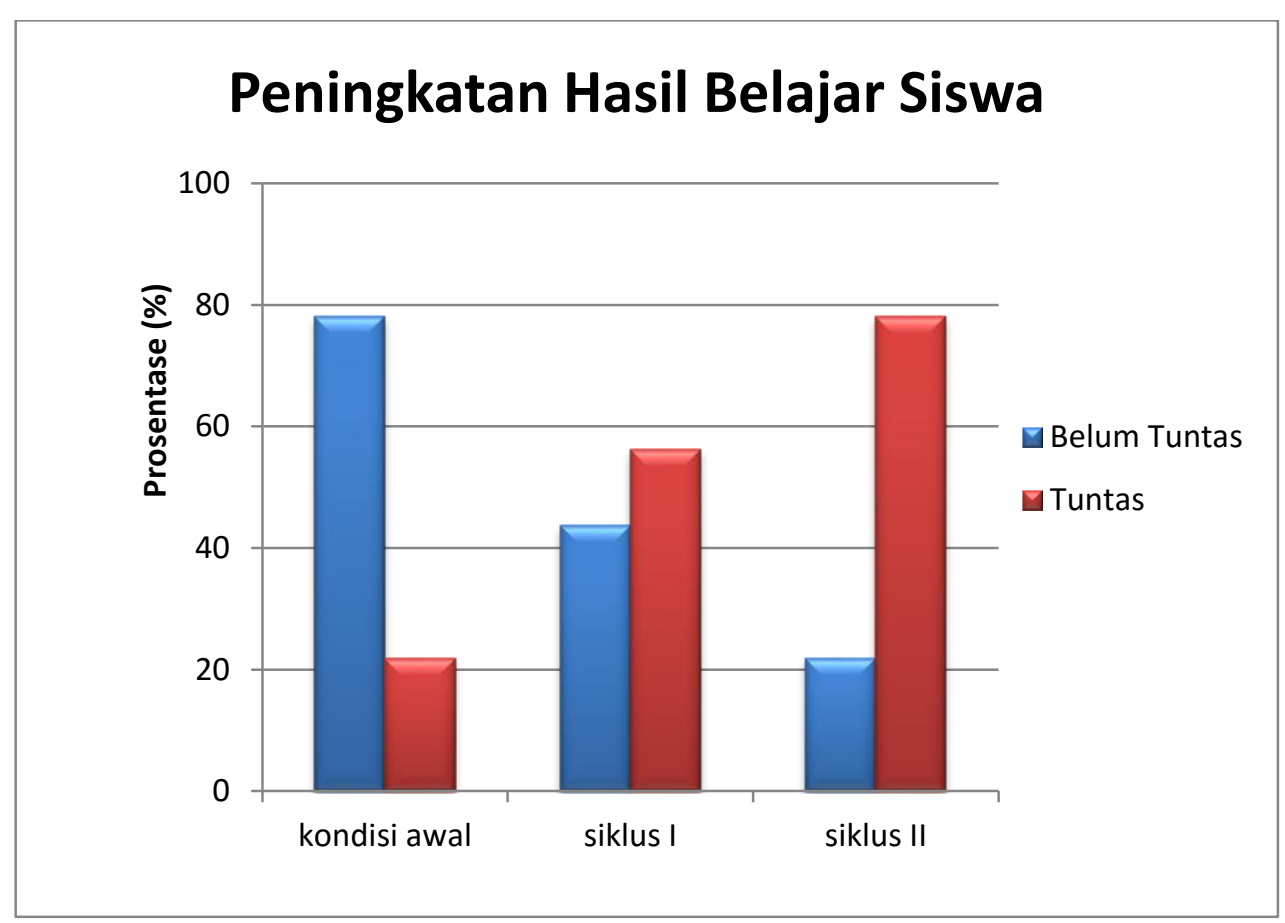

\section{Simpulan}

Penerapan model pembelajaran Contetual Teaching and Learning (CTL) dapat meningkatakan motivasi belajar siswa kelas VIII E SMP Negeri 14 Surakarta pada tahun ajaran 2015/2016. Hal ini dapat diketahui dari adanya peningkatan motivasi belajar siswa pada kategori tinggi sebelum tindakan yakni sebesar 31,25\%. Setelah dilaksanakan tindakan siklus I skor motivasi tinggi meningkat, namun masih belum mencapai target penelitian yakni sebesar $59,38 \%$. Pada tindakan siklus II skor motivasi tinggi meningkat menjadi sebesar $81,25 \%$.

Penerapan model pembelajaran Contetual Teaching and Learning (CTL) dapat meningkatakan hasil belajar siswa kelas VIII E SMP Negeri 14 Surakarta pada tahun ajaran 2015/2016. Hal ini dapat diketahui dari perolehan nilai hasil belajar dari pra tindakan, yakni siswa yang tuntas belajar atau mencapai batas KKM (>75) sebesar 21,87\%. Setelah dilakukan tindakan siklus I ketuntasan 
belajar siswa meningkat menjadi 56,25\%. Setelah dilakukan tindakan pada siklus II ketuntasan belajar siswa mencapai $78,12 \%$.

\section{Daftar Pustaka}

Arikunto, S. (2002). Dasar-dasar Evaluasi Pendidikan. Jakarta: Bumi Aksara . (2006). Penelitian Tindakan Kelas. Jakarta: Bumi Aksara. (2006). Prosedur Penelitian. Jakarta: Rineka Cipta

Budiyono. (2003). Metodologi Penelitian Pendidikan. Surakarta: UNS Press.

Dimyati dan Mudjiono. (1999). Belajar dan Pembelajaran. Jakarta: Rineka Cipta.

Hamdani. (2011). Strategi Belajar Mengajar. Bandung : Pustaka Setia.

Mulyasa, E. (2003). Kurikulum Berbasis Kompetensi. Bandung: Remaja Rosdakarya

- (2007). Menjadi Guru Profesional Menciptakan Pembelajaran Kreatif dan Menyenangkan. Bandung: PT. Remaja Rosdakarya

Nazarudin. (2007). Manajemen Pembelajaran Implementasi Konsep, Karakteristik dan Metodologi Pendidikan Agama Islam di Sekolah Umum. Yogyakarta:Penerbit Teras

Nurhadi. (2002). Pembelajaran Kontekstual dan Penerapannya dalam KBK. Malang: Universitas Negeri Malang.

Oemar Hamalik. (2003). Proses Belajar Mengajar. Jakarta: Bumi Aksara.

Prawiradilaga dan Siregar E.(2004). Mozaik Teknologi Pendidikan. Jakarta: Prenada Media

Puspasari, W. D.(2010). Meningkatkan Sikap Positif Siswa SMA Negeri 1 Muntilan Terhadap Matematika Melalui Pembelajaran Berbasis Masalah. Skripsi tidak dipublikasikan. Universitas Negeri Yogyakarta.

Robertus Angkowi dan A. Kosasih. (2007). Optimalisasi Media Pembelajaran. Jakarta: PT.Grafindo

Sanjaya, W. (2006). Strategi Pembelajaran: Berorientasi Standar Proses Pendidikan. Jakarta: Kencana Prenada Media Group.

Sardiman. (1990). Interaksi dan Motivasi Belajar Mengajar Pedoman Bagi Guru dan Calon Guru. Jakarta: Rajawali

Slameto. (1995). Belajar dan Faktor-faktor yang Mempengaruhinya. Jakarta: PT.Rineka Cipta

Sudjana, Nana. (2011).Penilaian Hasil Proses Belajar Mengajar. Bandung: PT. Remaja Rosdakarya

Sugihartono,dkk. (2010). Psikologi Pendidikan. Yogyakarta: UNY Press. 
Sugiyono.(2010). Metode Penelitian Pendidikan Pendekatan Kuantitatif, Kreatif, dan R\&D. Bandung: Alfabeta.

Sukmadinata, Nana Syaodih. (2003). Landasan Psikologi Proses Pendidikan. Bandung: PT: Remaja Rosdakarya.

Suparno, P. (2001). Filsafat Konstruktifisme dalam Pendidikan. Yogyakarta: Kanisius.

Tabrani dkk. (1989). Pendidikan Bagi Anak Berkesulitan Belajar. Jakarta Rineka Cipta.

Uno, Hamzah B.(2007). Teori Motivasi. Jakarta: Bumi Aksara. 